\title{
Carbon dioxide emission from drawdown areas of a Brazilian reservoir is linked to surrounding land cover
}

\author{
Rafael M. Almeida ${ }^{1,4}$ (1) $\cdot$ José R. Paranaíba ${ }^{1}$ Ícaro Barbosa ${ }^{1} \cdot$ Sebastian Sobek $^{2} \cdot$ Sarian Kosten $^{3} \cdot$ Annika Linkhorst $^{2}$. \\ Raquel Mendonça ${ }^{1,2} \cdot$ Gabrielle Quadra $^{1} \cdot$ Fábio Roland ${ }^{1} \cdot$ Nathan Barros $^{1}$
}

Received: 7 December 2018 / Accepted: 25 July 2019 / Published online: 21 August 2019

(c) The Author(s) 2019

\begin{abstract}
Reservoir sediments exposed to air due to water level fluctuations are strong sources of atmospheric carbon dioxide $\left(\mathrm{CO}_{2}\right)$. The spatial variability of $\mathrm{CO}_{2}$ fluxes from these drawdown areas are still poorly understood. In a reservoir in southeastern Brazil, we investigated whether $\mathrm{CO}_{2}$ emissions from drawdown areas vary as a function of neighboring land cover types and assessed the magnitude of $\mathrm{CO}_{2}$ fluxes from drawdown areas in relation to nearby water surface. Exposed sediments near forestland (average $=2733 \mathrm{mg} \mathrm{C} \mathrm{m}^{-2} \mathrm{day}^{-1}$ ) emitted more $\mathrm{CO}_{2}$ than exposed sediments near grassland (average $=1261 \mathrm{mg} \mathrm{C}$ $\mathrm{m}^{-2}$ day $\left.^{-1}\right)$, congruent with a difference in organic matter content between areas adjacent to forestland (average $\left.=12.2 \%\right)$ and grassland (average $=10.9 \%$ ). Moisture also had a significant effect on $\mathrm{CO}_{2}$ emission, with dry exposed sediments (average water content: $13.7 \%$ ) emitting on average 2.5 times more $\mathrm{CO}_{2}$ than wet exposed sediments (average water content: $23.5 \%$ ). We carried out a systematic comparison with data from the literature, which indicates that $\mathrm{CO}_{2}$ efflux from drawdown areas globally is about an order of magnitude higher than $\mathrm{CO}_{2}$ efflux from adjacent water surfaces, and within the range of $\mathrm{CO}_{2}$ efflux from terrestrial soils. Our findings suggest that emissions from exposed sediments may vary substantially in space, possibly related to organic matter supply from uphill vegetation, and that drawdown areas play a disproportionately important role in total reservoir $\mathrm{CO}_{2}$ emissions with respect to the area they cover.
\end{abstract}

Keywords Exposed sediment · Dry sediment $\cdot$ Carbon dioxide $\cdot$ Greenhouse gas · Dam

\section{Introduction}

Although reservoirs provide key services to humans, the construction of numerous dams worldwide has been resulting in a vast range of ecological and hydrological alterations (Nilsson et al. 2005). By the damming of rivers and

Rafael M. Almeida and José R. Paranaíba contributed equally to the manuscript.

Rafael M. Almeida

rafaelmarquesjf@yahoo.com.br

1 Department of Biology, Federal University of Juiz de Fora, Juiz de Fora, MG, Brazil

2 Department of Ecology and Genetics, Uppsala University, Uppsala, Sweden

3 Department of Aquatic Ecology and Environmental Biology, Radboud University Nijmegen, Nijmegen, The Netherlands

4 Present Address: Department of Ecology and Evolutionary Biology, Cornell University, Ithaca, NY, USA the resultant flooding of land, biogeochemical cycles in the original river and the flooded land areas are substantially altered (Friedl and Wüest 2002), which may result in increased greenhouse-gas emission (St. Louis et al. 2000). The most up-to-date review indicates that greenhouse-gas emission from reservoirs-predominantly as methane $\left(\mathrm{CH}_{4}\right)$ and carbon dioxide $\left(\mathrm{CO}_{2}\right)$-is responsible for $\sim 1.5 \%$ of the global anthropogenic $\mathrm{CO}_{2}$-equivalent emissions (Deemer et al. 2016). The importance of understanding spatial and temporal variability in order to reliably assess total carbon emission from reservoirs is getting increasingly evident (Descloux et al. 2017; Paranaíba et al. 2018; Teodoru et al. 2012; Roland et al. 2010; Yang et al. 2013). Nevertheless, existing studies on reservoir emissions focus almost exclusively on emission from the water surface. Emissions from drawdown areas are largely neglected and these areas are considered blind spots in the global carbon cycle (Marcé et al. 2019).

Drawdown areas are referred to as the margins of reservoirs that are, due to seasonal hydrological cycles or dam 
operation, subject to water level fluctuation that causes periods of inundation and desiccation. The extent of these areas increases dramatically during periods of prolonged droughts. For instance, the extreme drought of 2014/2015 in Brazil has resulted in an additional exposure to air of $\sim 1300 \mathrm{~km}^{2}$ of reservoir sediments throughout Brazil, which substantially enhanced carbon emission rates (Kosten et al. 2018). An increasing number of studies-all of them very recentindicate that exposed aquatic sediments are relevant net sources of atmospheric $\mathrm{CO}_{2}$ (Catalán et al. 2014; Hyojin et al. 2016; Marcé et al. 2019; Obrador et al. 2018; Schiller et al. 2014). An important factor supporting enhanced $\mathrm{CO}_{2}$ emission rates from exposed sediments is the increased microbial metabolism (e.g., enhanced enzyme activity of phenol oxidases and hydrolases) as sediment dries out (Hyojin et al. 2016; Weise et al. 2016). The importance of exposed sediments to reservoir carbon processing is clearly illustrated by a study in a Southeast Asian reservoir, which demonstrates that drawdown areas may contribute up to $75 \%$ of total annual $\mathrm{CO}_{2}$ emissions (Deshmukh et al. 2018). Globally, dry exposed sediments are estimated to emit $\sim 200 \mathrm{Tg}$ of carbon as $\mathrm{CO}_{2}$, which is equivalent to $\sim 10 \%$ of global $\mathrm{CO}_{2}$ emissions from inland waters (Marcé et al. 2019).

A more comprehensive understanding of carbon processing in drawdown areas is necessary for two principal reasons. First, there is growing evidence that exposed sediments are hotspots for carbon emission from freshwaters. Second, weather extremes can substantially affect $\mathrm{CO}_{2}$ fluxes from freshwater systems (Almeida et al. 2017; Kosten et al. 2018), and the increased frequency of weather extremes associated with climate change is enhancing the desiccation of freshwater systems (Pekel et al. 2016) as well as the subsequent extent of drawdown areas (Kosten et al. 2018). Understanding the variability of $\mathrm{CO}_{2}$ fluxes from drawdown areas over time and space is fundamental to support the definition of adequate sampling strategies and thus more realistic upscaling of $\mathrm{CO}_{2}$ emissions from freshwater systems. While one study has reported limited spatial and annual variability in drawdown area $\mathrm{CO}_{2}$ fluxes (Deshmukh et al. 2018), the scarcity of data makes it difficult to draw general conclusions about spatial or temporal variability of drawdown area $\mathrm{CO}_{2}$ emission. Here we investigate the spatial variation in $\mathrm{CO}_{2}$ fluxes from the drawdown areas of a reservoir in southeastern Brazil. More specifically, we studied whether emission varies as a function of neighboring land cover types (i.e., forestland and grassland), since drawdown areas are transitional zones between aquatic and terrestrial ecosystems and, as such, are presumably influenced by both adjacent ecosystems. We further gauged the relative importance of drawdown zone emissions by assessing the magnitude of $\mathrm{CO}_{2}$ emission from the drawdown areas in relation to water surface emissions on a seasonal and interannual time scale. Lastly, we compared the measured drawdown $\mathrm{CO}_{2}$ emission with reported $\mathrm{CO}_{2}$ fluxes from reservoir water surfaces and terrestrial soils worldwide, to understand whether exposed sediments align with terrestrial or aquatic ecosystems with respect to $\mathrm{CO}_{2}$ emission.

\section{Methods}

\section{Study area and quantification of drawdown areas}

Chapéu D'Uvas (CDU) reservoir $\left(21^{\circ} 33^{\prime} \mathrm{S}, 43^{\circ} 35^{\prime} \mathrm{W}\right)$ is an oligotrophic water supply reservoir constructed in 1994 in the Paraibuna River, Minas Gerais state, southeastern Brazil. The land cover of the reservoir's watershed is composed of grassland $(\sim 66 \%)$, natural forest $(\sim 30 \%)$, and Eucalyptus plantation $(\sim 4 \%)$ (Machado 2012). To estimate the total reservoir area, we contoured the reservoir shape on Google Earth based on satellite images from four periods with different water levels and generated a regression between water level and flooded area (flooded area $=0.4117 \times$ water level $\left.-293.68 ; r^{2}=0.91, p<0.05, n=4\right)$. We then used daily water level data to calculate daily flooded area. Between November 2014 and August 2017, the flooded area ranged between 7.0 and $10.6 \mathrm{~km}^{2}$. The difference between maximum and minimum flooded area was assumed to be the maximum drawdown area (i.e., $3.6 \mathrm{~km}^{2}$ ), and the drawdown area was assumed to be zero at maximum flooded area. Daily drawdown area was then calculated by subtracting daily flooded area from the maximum flooded area.

\section{$\mathrm{CO}_{2}$ flux from water surface}

We estimated $\mathrm{CO}_{2}$ fluxes from open water surface during four sampling campaigns over hydrologically different seasons in 2015 and 2016. We used a combination of online equilibration system surveys and floating chamber measurements along the reservoir (see Paranaíba et al. 2018 for details on the approach). We performed continuous measurements ( $1-\mathrm{Hz}$ frequency) of dissolved $\mathrm{CO}_{2}$ concentrations in surface water using an open gas-flow equilibration system connected to an Ultra-portable Greenhouse Gas Analyzer (UGGA, Los Gatos Research, detection limit: $1.5 \times 10^{-7} \mathrm{~mol}$ $\mathrm{L}^{-1}$ ). We attached the inlet of the online equilibration system to the boat at $0.5 \mathrm{~m}$ depth, so that water was continuously pumped into the system $\left(3 \mathrm{~L} \mathrm{~min}^{-1}\right)$ while the boat navigated through the reservoir at $\sim 7 \mathrm{~km} \mathrm{~h}^{-1}$. Each kilometer, the boat was stopped and the dissolved $\mathrm{CO}_{2}$ measurements were interrupted for the measurements of the $\mathrm{CO}_{2}$ gas exchange coefficient (described below).

We connected a transparent acrylic floating chamber (cylindrical, $17 \mathrm{~L}, 0.07 \mathrm{~m}^{2}$ ) to the UGGA in a closed gas loop, and $\mathrm{CO}_{2}$ concentration was monitored over 5-min intervals. Measurements were done in triplicates at each 
sampling spot. At each spot, we also took discrete samples of surface water in triplicates for the determination of $\mathrm{CO}_{2}$ surface water concentrations according to the headspace technique (Cole and Caraco 1998). From these discrete samples, we further computed the $\mathrm{CO}_{2}$ gas exchange coefficient following the equation below:

$k_{\mathrm{CO}_{2}}=\frac{C_{w}-C_{e q}}{F_{\mathrm{CO}_{2}}}$

where $k_{\mathrm{CO}_{2}}\left(\mathrm{~m} \mathrm{day}^{-1}\right)$ is the gas exchange coefficient for $\mathrm{CO}_{2}$; $C_{w}\left(\mathrm{mmol} \mathrm{m}^{-3}\right)$ is the concentration of $\mathrm{CO}_{2}$ in water and $\mathrm{C}_{\mathrm{eq}}\left(\mathrm{mmol} \mathrm{m}^{-3}\right)$ is the theoretical concentration of $\mathrm{CO}_{2}$ in water if the water phase was in equilibrium with the atmosphere, both calculated from the discrete samples; and $\mathrm{F}_{\mathrm{CO}_{2}}$ $\left(\mathrm{mmol} \mathrm{m}{ }^{-2}\right.$ day $\left.^{-1}\right)$ is the $\mathrm{CO}_{2}$ flux at the air-water interface, calculated from the floating chambers measurements.

We then combined the $\mathrm{CO}_{2}$ concentrations from the online equilibration system with $k_{\mathrm{CO}_{2}}$ to compute $\mathrm{CO}_{2}$ emissions for the entire reservoir during each of the four campaigns. Specific details about the online equilibration system, floating chamber and discrete sample measurements, as well as flux calculation can be found in Paranaíba et al. 2018.

\section{$\mathrm{CO}_{2}$ flux from drawdown areas}

We assessed the spatial variation of $\mathrm{CO}_{2}$ fluxes from drawdown areas during the wet season in January 2018 (nine sites) and during the dry season in August 2018 (eight sites) using static chambers (cylindrical, $6.24 \mathrm{~L}, 0.07 \mathrm{~m}^{2}$ ). To capture potential spatial variation related to neighboring land cover, we sampled sites in the drawdown area adjacent to the two main land cover types of the CDU watershed (forestland and grassland), which correspond to $~ 95 \%$ of the land cover. These land cover types were heterogeneously distributed along the reservoir (Fig. 1). At each sampling site, we measured $\mathrm{CO}_{2}$ flux in triplicates in three different areas: underwater shoreline (1-3 cm water depth), wet exposed sediments and dry exposed sediments (Fig. 2), totaling nine chamber measurements per sampling site. We made the distinction between wet and dry sediment visually (Fig. 2) and further confirmed that through moisture analysis in the laboratory - the average water contents of wet and dry exposed sediments were $24 \pm 5 \%( \pm \mathrm{SD})$ and $13 \pm 4 \%( \pm \mathrm{SD})$ of total weight, respectively. The triplicated chambers were deployed about $1 \mathrm{~m}$ apart from each other and connected to an Infrared Gas Analyzer (IRGA EGM-4 PP Systems) for five minutes to quantify changes in $\mathrm{CO}_{2}$ concentration over

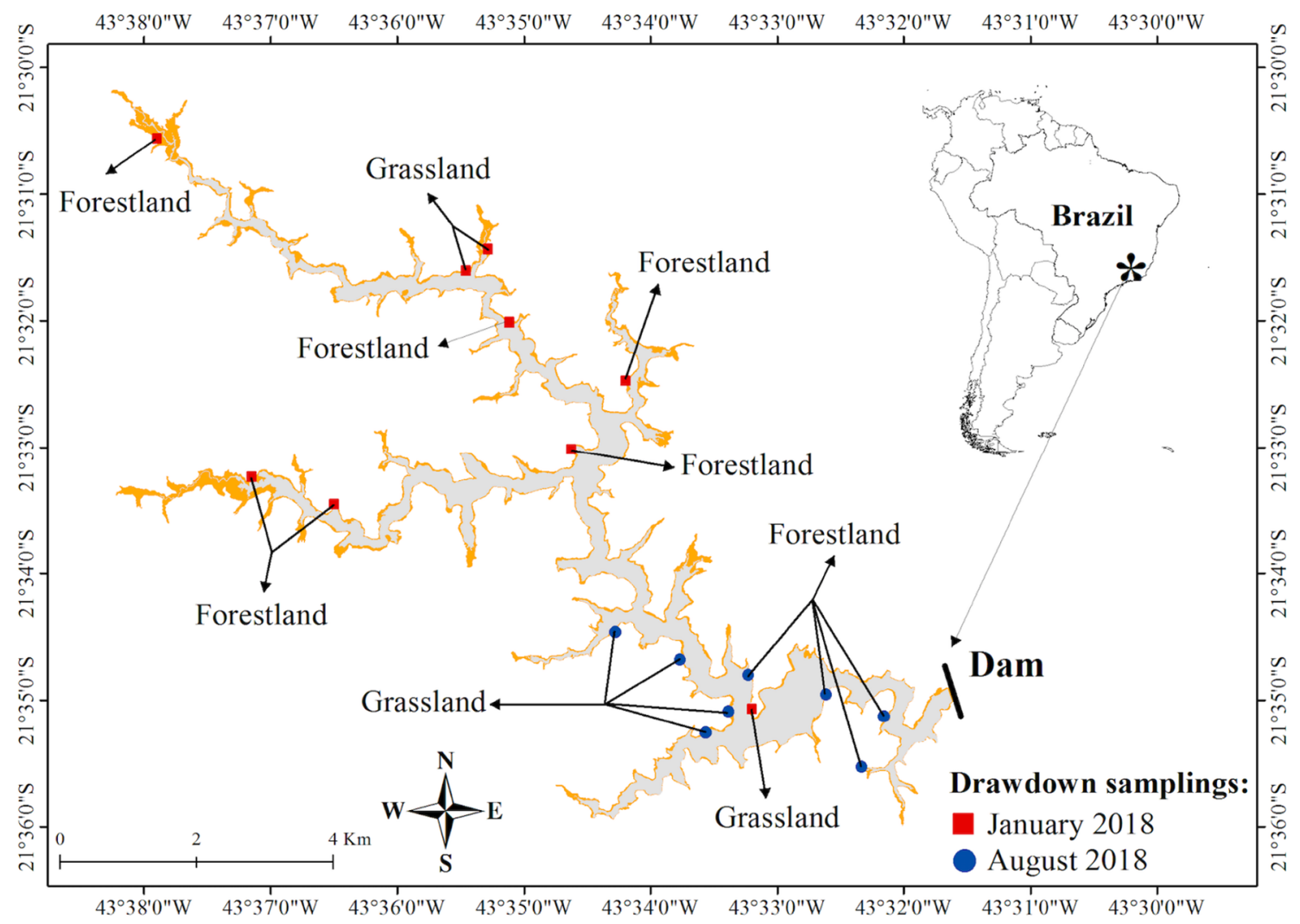

Fig. 1 Map of Chapéu D’Uvas (CDU) reservoir, with drawdown areas highlighted in orange. The sampling sites for static chambers deployed to measure $\mathrm{CO}_{2}$ fluxes from drawdown areas are shown in the map 
Fig. 2 Photograph taken in May 2017 depicting a typical drawdown area of Chapéu D'Uvas (CDU) reservoir. We deployed static chambers connected to a portable gas analyzer to measure $\mathrm{CO}_{2}$ fluxes at the underwater shoreline, wet exposed sediment, and dry exposed sediment

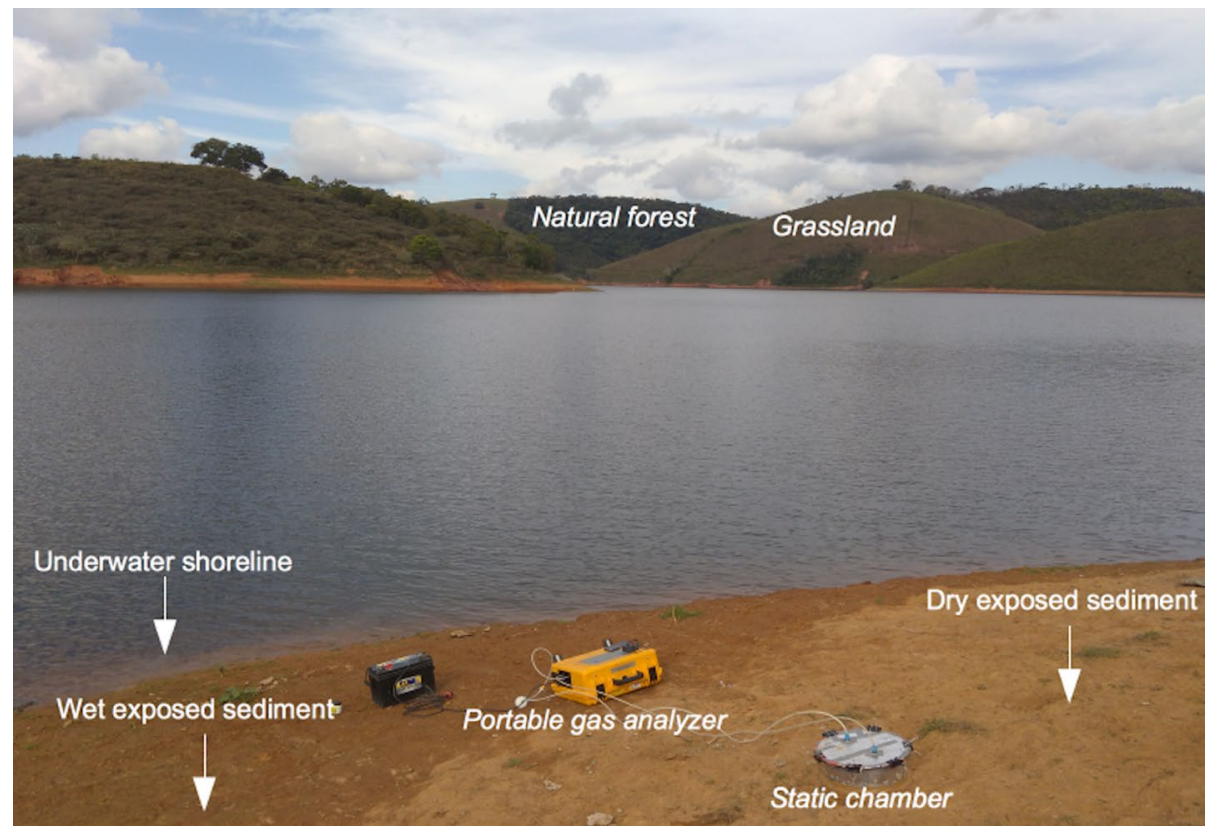

time. The chambers were opaque to minimize temperature change. We used clay around the exterior of the chambers to avoid gas leakage (Lesmeister and Koschorreck 2017). Soil temperature and conductivity were determined using a conductivity meter (Akrom KR31). Surface soil samples of exposed sediments (wet and dry) were collected after each measurement and stored in coolers for laboratory analysis of moisture and organic matter content within 2 days. Moisture content was measured as the weight loss after drying $10 \mathrm{~g}$ of sediment sample at $105^{\circ} \mathrm{C}$ for $2 \mathrm{~h}$. The samples used for moisture analysis were further used to quantify the organic matter content, which was measured as loss on ignition $\left(450{ }^{\circ} \mathrm{C}\right.$ for $\left.4 \mathrm{~h}\right)$.

We also performed measurements of $\mathrm{CH}_{4}$ emission from drawdown areas at one grassland-neighbored site in May 2017, using static chambers connected to a UGGA. While $\mathrm{CH}_{4}$ fluxes from exposed sediments can be important in some reservoir systems, these preliminary measurements indicated $\mathrm{CH}_{4}$ uptake (4 mg $\mathrm{CO}_{2} \mathrm{eq} \mathrm{m}^{-2}$ day ${ }^{-1}$, 100-year global warming potential of 34; data not shown). The magnitude of that uptake is, however, negligible compared to the magnitude of $\mathrm{CO}_{2}$ emissions measured over the same time period (1452 $\mathrm{mg} \mathrm{CO}_{2} \mathrm{~m}^{-2} \mathrm{day}^{-1}$ ), and $\mathrm{CH}_{4}$ uptake thus canceled less than $1 \%$ of $\mathrm{CO}_{2}$ emissions. Our study therefore focuses exclusively on $\mathrm{CO}_{2}$.

\section{Data analysis}

We used analyses of variance to evaluate the effects of season, moisture and neighboring land cover on $\mathrm{CO}_{2}$ flux, as well as the interaction between these two predictors. We log-transformed the $\mathrm{CO}_{2}$ fluxes to meet the assumptions of normality and homoscedasticity and applied the aov function of R Statistical Software version 3.3.2 (R Development Core Team 2016).

We further compared $\mathrm{CO}_{2}$ fluxes from exposed sediments of CDU reservoir with fluxes reported in the literature for exposed sediments of other freshwater systems, reservoir surfaces, and terrestrial soils. $\mathrm{CO}_{2}$ fluxes from reservoir surfaces were taken from a recent compilation of $\mathrm{CO}_{2}$ emissions from 228 reservoirs worldwide (Deemer et al. 2016). $\mathrm{CO}_{2}$ fluxes from terrestrial soils were taken from a global database of soil respiration from all types of ecosystems worldwide (Bond-Lamberty and Thomson 2012).

\section{Results and discussion}

\section{Extent of drawdown areas}

The relative share of drawdown areas to the total area of CDU reservoir varies seasonally and interanually (Fig. 3). The share was smallest right after the rainy season $(<1 \%$ between March and May 2016) and largest right after the dry season ( $>30 \%$ in November and December 2014). In 2015 , drawdown areas accounted on average for $24 \%$ of the total reservoir area, whereas in 2016 they accounted for $7 \%$. According to the Brazilian National Institute of Meteorology (INMET; http://www.inmet.gov.br), the average annual rainfall near CDU (Juiz de Fora station) is $1597 \mathrm{~mm}$. The INMET reports that 2014 and 2015 were characterized by below-normal total rainfall (906 and $1251 \mathrm{~mm}$, respectively), whereas 2016 had above-normal total rainfall (1705 mm). Interannual variation in rainfall thus explains the high 


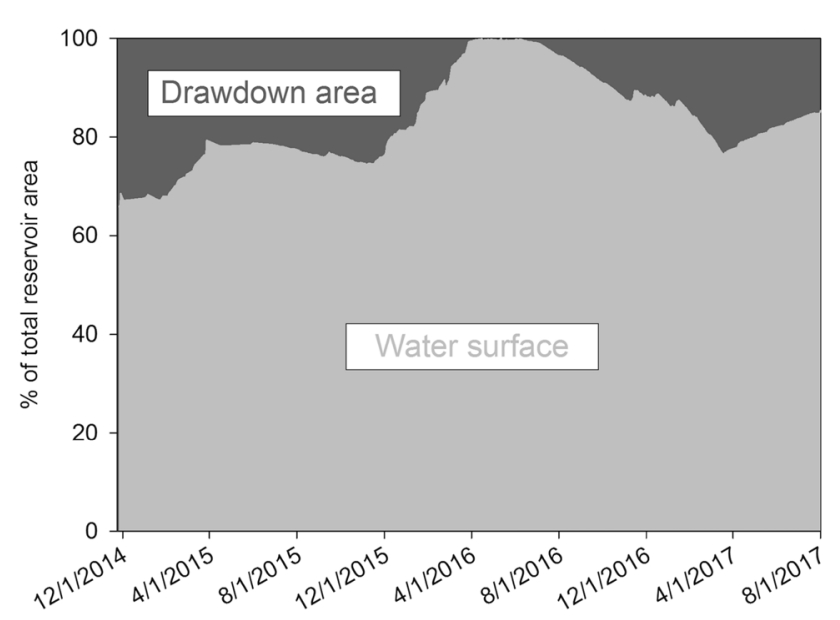

Fig. 3 Relative contribution of drawdown area (dark grey) and water surface area (light grey) to the total reservoir area of Chapéu D'Uvas (CDU) reservoir over time

interannual variation in the share of drawdown areas to the total reservoir area. On average, drawdown areas accounted for $17 \%$ of the total reservoir area between November 2014 and August 2017.

\section{$\mathrm{CO}_{2}$ fluxes in drawdown areas}

The average $\mathrm{CO}_{2}$ emission from exposed sediments in drawdown areas of CDU reservoir was $1855 \mathrm{mg} \mathrm{C} \mathrm{m}^{-2}$ day $^{-1}$ (range: $204-6425 \mathrm{mg} \mathrm{C} \mathrm{m}^{-2}$ day $^{-1}, \mathrm{n}=18$ ) during the wet season in January 2018 and $2432 \mathrm{mg} \mathrm{C} \mathrm{m}^{-2}$ day $^{-1}$ (range 163-6857 $\mathrm{mg} \mathrm{C} \mathrm{m}^{-2}$ day $^{-1}, \mathrm{n}=16$ ) during the dry season in August 2018. The seasonal difference in $\mathrm{CO}_{2}$ emission from exposed sediments was not significant $(\mathrm{F}=0.5$, $\mathrm{p}=0.48, \mathrm{df}=33$ ). Underwater shoreline areas near exposed sediments had average emissions of $353 \mathrm{mg} \mathrm{C} \mathrm{m}^{-2}$ day $^{-1}$

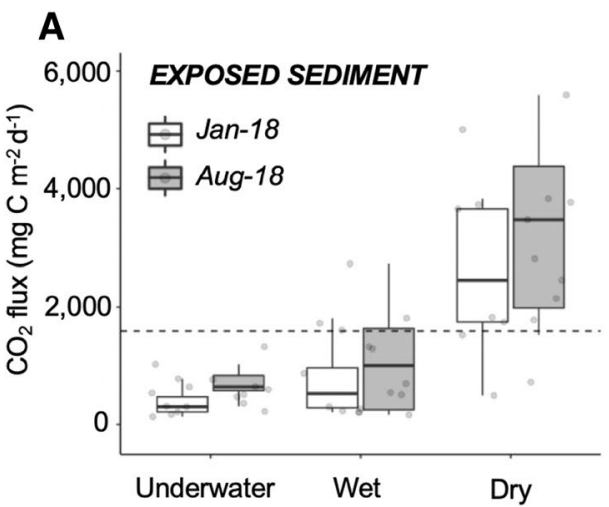

Fig. $4 \mathrm{CO}_{2}$ fluxes from (A) exposed sediment (underwater shoreline, wet exposed sediments, and dry exposed sediments) in January and August 2018, and (B) the water surface in September 2015, December 2015, April 2016 and August 2016 in Chapéu D’Uvas reservoir. (range: $130-776 \mathrm{mg} \mathrm{C} \mathrm{m}^{-2}$ day $^{-1}, \mathrm{n}=9$ ) in January 2018 and $726 \mathrm{mg} \mathrm{C} \mathrm{m}^{-2}$ day $^{-1}$ (range $310-1330 \mathrm{mg} \mathrm{C} \mathrm{m}^{-2}$ day $^{-1}$, $\mathrm{n}=8$ ) in August 2018. Notably, the rates of $\mathrm{CO}_{2}$ efflux from the reservoir drawdown areas were on average 19 (January 2018) to 26 (August 2018) times higher than the average $\mathrm{CO}_{2}$ efflux from the reservoir water surface $\left(71 \mathrm{mg} \mathrm{C} \mathrm{m}^{-2}\right.$ day $^{-1}$; Fig. 4a, b).

$\mathrm{CO}_{2}$ emissions significantly differed between dry exposed sediments, wet exposed sediments, and neighboring underwater shoreline in both January $2018(\mathrm{~F}=10.9, \mathrm{p}<0.05$, $\mathrm{df}=26)$ and August $2018(\mathrm{~F}=11.8, \mathrm{p}<0.05, \mathrm{df}=23)$ (Fig. 4a). A Tukey post hoc test indicated higher emissions from dry exposed sediments than from wet exposed sediments (January: $\mathrm{t}=2.5, \mathrm{p}<0.05$; August: $\mathrm{t}=4.1, \mathrm{p}<0.05$ ) and underwater shoreline (January: $\mathrm{t}=4.7, \mathrm{p}<0.05$; August: $\mathrm{t}=4.3, \mathrm{p}<0.05)$ in both seasons. In contrast, there was no difference between emissions from wet exposed sediments and underwater shoreline in either January $(\mathrm{t}=2.1, \mathrm{p}=0.10)$ or August $(t=0.2, p=0.98)$. Our results are in agreement with other recent studies reporting increasing $\mathrm{CO}_{2}$ efflux as exposed sediments dry out (Gilbert et al. 2017; Weise et al. 2016). We did not measure how long it takes for exposed sediments to transition from wet to dry, and this merits further investigation. The transition time is likely variable and may be influenced by many factors including solar irradiance, wind conditions, precipitation, temperature, and slope of the exposed area.

Cycles of wetting-desiccation accelerate carbon losses from freshwater systems (Reverey et al. 2016). Indeed, a growing number of studies in different types of aquatic ecosystems (reservoirs, intermittent streams, temporary ponds) suggest that exposed sediments emit substantially more $\mathrm{CO}_{2}$ than adjacent water surfaces (Catalán et al. 2014; Deshmukh et al. 2018; Gilbert et al. 2017; Gómez-Gener et al. 2015; Hyojin et al. 2016; Looman et al. 2017; Obrador

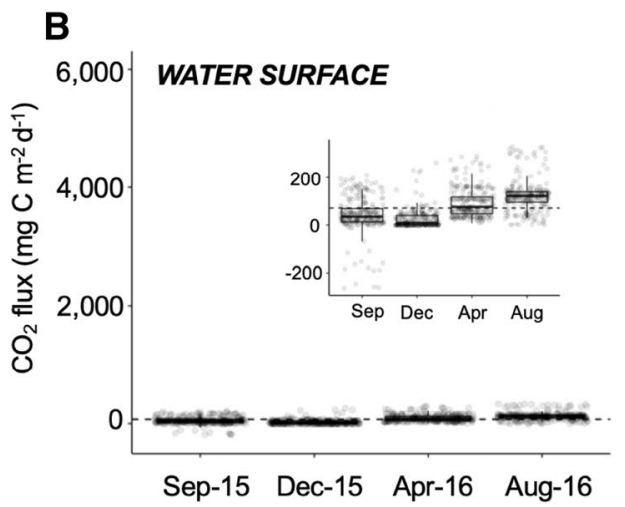

The inset figure in B shows the water surface results on a different scale for better visualization of the seasonal variability. The lines within the boxes indicate the median, the boxes delimit the 25th and 75th percentiles, and the whiskers delimit the 5th and 95th percentiles 
et al. 2018; Schiller et al. 2014). Higher $\mathrm{CO}_{2}$ emission from exposed sediments compared to nearby water surfaces have been attributed to enhanced microbial metabolism: sediment desiccation stimulates bacterial growth and enzyme activity, which in turn enhances $\mathrm{CO}_{2}$ production and subsequent efflux (Fenner and Freeman 2011; Hyojin et al. 2016; Weise et al. 2016). The solubility of oxygen in water is low and its diffusivity slow (Furrer and Wehrli 1996), such that in waterlogged sediments oxygen supply to microbes is probably slow, which limits degradation rates (Zehnder and Svensson 1986). Once the void pore space in the sediments fills with air when sediment dries out, it is likely that microbial degradation rates are enhanced, increasing $\mathrm{CO}_{2}$ production. In combination with the higher diffusion rates, this may then lead to higher $\mathrm{CO}_{2}$ emission rates.

In addition to being affected by moisture, $\mathrm{CO}_{2}$ emission from exposed sediments was significantly different among sites grouped according to the predominant land cover adjacent to the sampling locations (Fig. 5). Exposed sediments near forestland exhibited significantly higher $\mathrm{CO}_{2}$ emission rates than those near grassland in both January $(\mathrm{F}=7.8$, $\mathrm{p}<0.05, \mathrm{df}=17)$ and August $(\mathrm{F}=5.6, \mathrm{p}<0.05, \mathrm{df}=15)$. Unlike exposed sediments, $\mathrm{CO}_{2}$ fluxes from underwater shoreline did not vary significantly among sites grouped according to the predominant adjacent land cover in either January $(\mathrm{F}=0.2, \mathrm{p}=0.68, \mathrm{df}=8)$ or August $(\mathrm{F}=0.5$, $\mathrm{p}=0.49, \mathrm{df}=7)$. Although thin $(<3 \mathrm{~cm}$ of depth), the layer of water above the sediment in underwater shoreline areas is still connected to pelagic water, such that $\mathrm{CO}_{2}$ can be transported laterally, which may explain the more homogeneous spatial variability in these compartments compared to areas of exposed sediment.

We found that exposed sediments adjacent to forestland had higher organic matter concentrations (average $=14.9 \%$ of dry weight) than those next to grassland (average $=11.3 \%$ of dry weight) in August (one-tailed $t$ test, $\mathrm{t}=1.9, \mathrm{p}<0.05$, $\mathrm{df}=14$ ). In January, however, we could not detect a significant difference between the organic matter content of exposed sediments in forestland- (average $=10.4 \%)$ and grassland-neighbored areas (average $=9.2 \%$; one-tailed $t$ test, $\mathrm{t}=0.9, \mathrm{p}=0.19, \mathrm{df}=15$ ) (Fig. 6). The substantial variability in organic matter content in exposed sediment within each group of adjacent land cover (Fig. 6) indicates that uphill forests may export more organic matter to neighboring exposed sediments than grassland areas, which may in part explain the higher $\mathrm{CO}_{2}$ emission rates observed in drawdown areas adjacent to forestland.

\section{Relative contribution of drawdown areas to total reservoir $\mathrm{CO}_{2}$ emissions}

To estimate the relative annual contribution of drawdown areas to total $\mathrm{CO}_{2}$ emissions from $\mathrm{CDU}$ reservoir, we considered the average values of all water surface (September 2015, December 2015, April 2016 and August 2016)

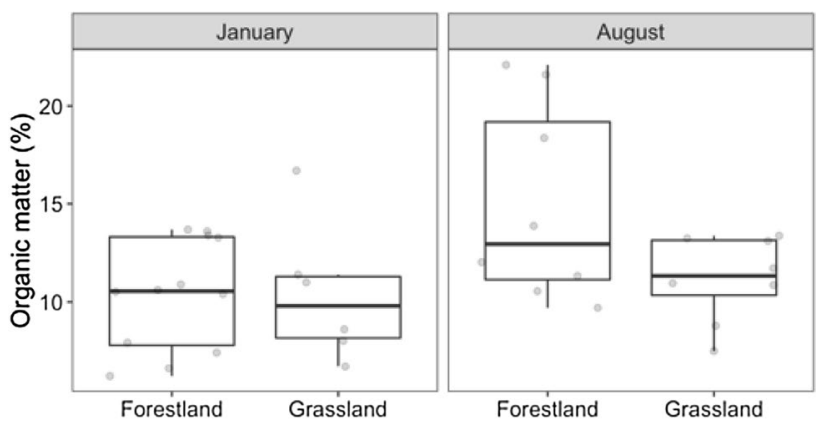

Fig. 6 Concentrations of organic matter (in percentage of dry weight) in exposed sediments of Chapéu D'Uvas reservoir in January and August 2018. The lines within the boxes indicate the median, the boxes delimit the $25^{\text {th }}$ and $75^{\text {th }}$ percentiles, and the whiskers delimit the $5^{\text {th }}$ and $95^{\text {th }}$ percentiles
Fig. $5 \mathrm{CO}_{2}$ fluxes from underwater shoreline, wet exposed sediment, and dry exposed sediment (left to right) in areas neighbored by forestland and grassland in Chapéu D'Uvas reservoir. The lines within the boxes indicate the median, the boxes delimit the $25^{\text {th }}$ and $75^{\text {th }}$ percentiles, and the whiskers delimit the $5^{\text {th }}$ and $95^{\text {th }}$ percentiles
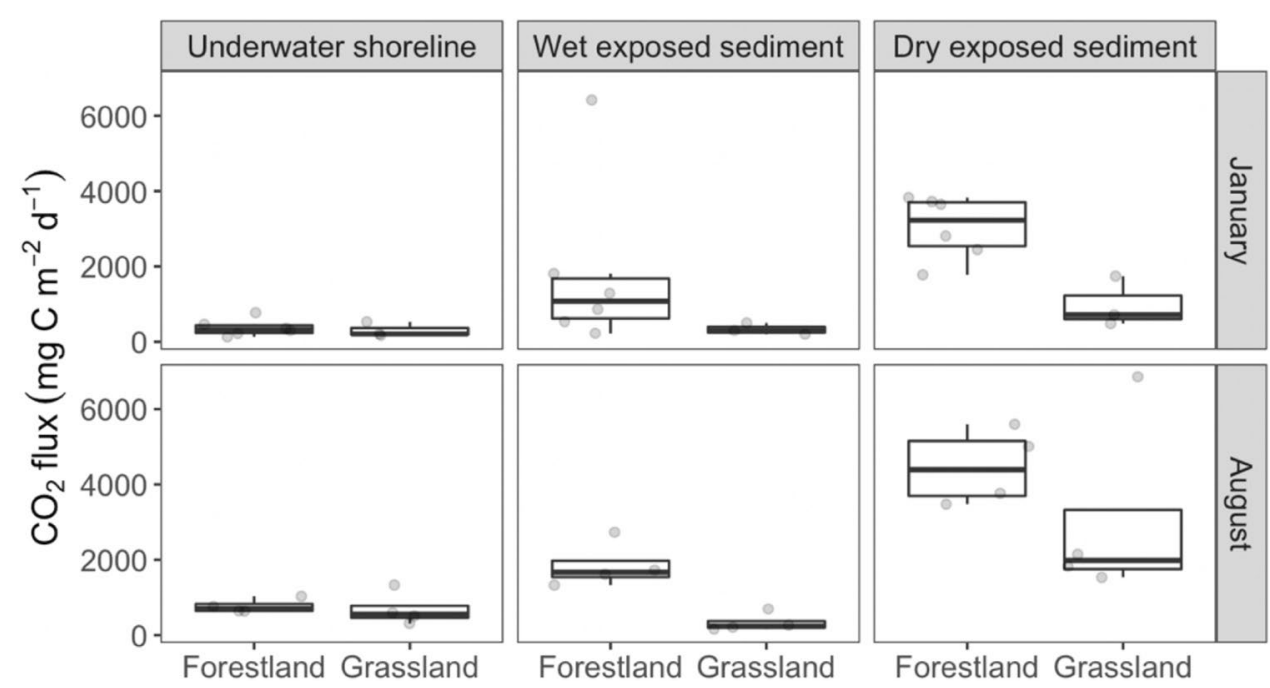

Forestland Grassland 
and drawdown (January and August 2018) measurements. These calculations were made considering the average CDU basin land cover ( $\sim 66 \%$ grassland and $34 \%$ forestland). The weighted average $\mathrm{CO}_{2}$ emission from the $\mathrm{CDU}$ drawdown area was $1736 \mathrm{mg} \mathrm{C} \mathrm{m}^{-2} \mathrm{day}^{-1}$, and this gives a total $\mathrm{CO}_{2}$ emission of $3038 \mathrm{~kg} \mathrm{C}^{-1 a y}{ }^{-1}$ for $1.75 \mathrm{~km}^{2}$ of drawdown area (i.e., the average extent of the drawdown area over time). The average $\mathrm{CO}_{2}$ emission from the $\mathrm{CDU}$ water surface was $71 \mathrm{mg} \mathrm{C} \mathrm{m}^{-2}$ day $^{-1}$, and this gives a total $\mathrm{CO}_{2}$ emission of $628 \mathrm{~kg} \mathrm{C}$ day $^{-1}$ for $8.85 \mathrm{~km}^{2}$ of water surface area (i.e., the average extent of the reservoir water surface area over time). The drawdown area thus accounted for $<20 \%$ of the total reservoir area but contributed to $>80 \%$ of total reservoir $\mathrm{CO}_{2}$ emissions upstream the dam. Our results are in line with a recent study conducted in a reservoir in Southeast Asia, which found that drawdown areas accounted for $50-75 \%$ of

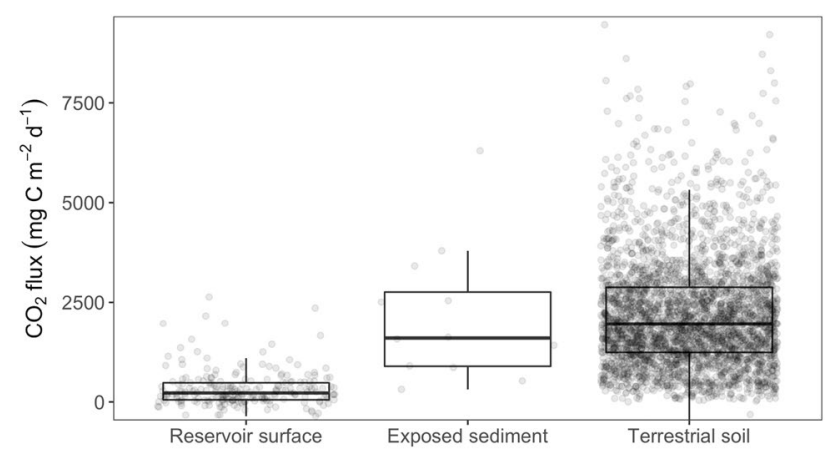

Fig. $7 \mathrm{CO}_{2}$ fluxes from exposed sediment of freshwater systems, reservoir surface and terrestrial soils worldwide. Data on exposed sediment were compiled from published literature and are shown as median or mean fluxes of each study (Table 1), data on reservoir surface were taken from (Deemer et al. 2016), and data on terrestrial soil were taken from (Bond-Lamberty and Thomson 2012) total annual reservoir $\mathrm{CO}_{2}$ emission (Deshmukh et al. 2018). Our findings indicate that drawdown areas are $\mathrm{CO}_{2}$ emission hotspots in CDU reservoir, not only due to high emission rates in relation to reservoir water surface, but also because exposed sediments cover a large fraction of the total reservoir area over long periods of the year (Fig. 3).

\section{$\mathrm{CO}_{2}$ emission from drawdown zones and other freshwater systems worldwide}

In order to quantitatively compare our findings, we compiled data from reservoir water surfaces and exposed sediments of freshwater systems worldwide (Fig. 7). The average flux from the drawdown zone of CDU reservoir $\left(1736 \mathrm{mg} \mathrm{C} \mathrm{m}^{-2}\right.$ $\mathrm{day}^{-1}$ ) is close to the average flux from exposed sediments of reservoirs, intermittent streams, and temporary ponds worldwide $\left(2145 \pm 1637 \mathrm{mg} \mathrm{C} \mathrm{m}^{-2} \mathrm{day}^{-1}\right.$, average \pm standard deviation, Table 1). The average $\mathrm{CO}_{2}$ flux from global exposed sediments is roughly one order of magnitude higher than the average $\mathrm{CO}_{2}$ flux from global reservoir surfaces (332 $\mathrm{mg} \mathrm{C} \mathrm{m}^{-2}$ day $^{-1}$ ) (Fig. 7), which is a similar pattern as observed in CDU reservoir data alone (Fig. 4). Although studies on $\mathrm{CO}_{2}$ emissions from drawdown areas are scarce, existing data suggest that the range of $\mathrm{CO}_{2}$ flux from drawdown zones resembles the range of $\mathrm{CO}_{2}$ flux from terrestrial soils rather than from reservoir water surfaces (Fig. 7). This has also been suggested by two separate studies in Mediterranean ecosystems (Gómez-Gener et al. 2015; Schiller et al. 2014). Importantly, however, terrestrial soil respiration is often counteracted by primary production from overlying vegetation, which typically results in positive net ecosystem production (i.e., net $\mathrm{CO}_{2}$ sinks) in terrestrial ecosystems. In terrestrial sites with reported measurements of both soil respiration and net ecosystem production in the global soil

Table 1 Mean fluxes of $\mathrm{CO}_{2}$ from exposed sediments of different types of freshwater systems worldwide reported in literature

\begin{tabular}{|c|c|c|c|c|}
\hline Site & Type & Country & $\begin{array}{l}\mathrm{CO}_{2} \text { flux }(\mathrm{mg} \\
\left.\mathrm{C} \mathrm{m}^{-2} \mathrm{day}^{-1}\right)\end{array}$ & References \\
\hline Nan Theum 2 Reservoir & Reservoir drawdown & Lao PDR & 3414 & Deshmukh et al. (2018) \\
\hline Fluvià River & Dry streambed & Spain & 2508 & $\begin{array}{l}\text { Gómez-Gener et al. (2015) and Schiller et al. } \\
\text { (2014) }\end{array}$ \\
\hline Lake Soyang & Reservoir drawdown & South Korea & 6300 & Hyojin et al. (2016) \\
\hline River Po & Exposed river sediment & Italy & 317 & Bolpagni et al. (2017) \\
\hline Temporary ponds on Menorca Island & Temporary pond & Spain & 1576 & Catalán et al. (2014) and Obrador et al. (2018) \\
\hline Experimental temporary ponds & Temporary pond & England & 3792 & Gilbert et al. (2017) \\
\hline Rappbode Reservoir & Reservoir drawdown & Germany & 1620 & Lesmeister and Koschorreck (2017) \\
\hline Elbe River & Exposed river sediment & Germany & 900 & Lesmeister and Koschorreck (2017) \\
\hline Jamison Creek & Dry streambed & Australia & 864 & Looman et al. (2017) \\
\hline Urban temporary streams & Dry streambed & United States & 528 & Gallo et al. (2014) \\
\hline Chinese hydropower reservoirs & Reservoir drawdown & China & 2110 & Li et al. (2015) \\
\hline Chapéu D’Uvas Reservoir & Reservoir drawdown & Brazil & 1736 & This study \\
\hline
\end{tabular}


respiration database (Bond-Lamberty and Thomson 2012), although the average soil $\mathrm{CO}_{2}$ efflux is high $(2148 \mathrm{mg} \mathrm{C}$ $\mathrm{m}^{-2}$ day $\left.^{-1}\right)$, the average net ecosystem production is positive (460 $\mathrm{mg} \mathrm{C} \mathrm{m}^{-2}$ day $^{-1}$ ). This indicates that despite elevated soil respiration, these terrestrial sites are overall net $\mathrm{CO}_{2}$ sinks when the primary production of overlying vegetation is taken into account. Our findings suggest that exposed aquatic sediments respire organic matter at a similar rate as terrestrial soils, but unlike terrestrial sites they end up functioning as strong $\mathrm{CO}_{2}$ sources since they frequently lack primary producers to compensate for $\mathrm{CO}_{2}$ production during microbial respiration.

\section{Implications and future directions}

Most studies focusing on $\mathrm{CO}_{2}$ emissions from exposed sediment are fairly recent (Table 1), and this area of research has been receiving increasing attention in the scientific literature. To our knowledge, our study is the first to demonstrate that $\mathrm{CO}_{2}$ fluxes from drawdown areas vary significantly in space, which is possibly related to the adjacent land cover. In addition to demonstrating the importance of spatial dynamics for a comprehensive understanding of $\mathrm{CO}_{2}$ fluxes from drawdown areas, our study presents a systematic comparison of reservoir water surface, freshwater drawdown, and soil fluxes of $\mathrm{CO}_{2}$. Even though we could not find significant seasonal variability in drawdown $\mathrm{CO}_{2}$ fluxes, our study is based on only two points in time, and does not preclude the existence of temporal variation of $\mathrm{CO}_{2}$ fluxes from drawdown areas.

The pattern observed in CDU reservoir, with $\mathrm{CO}_{2}$ emissions from drawdown areas exceeding those from the water surface, concurs with other freshwater systems around the globe (Fig. 7). Globally, $\mathrm{CO}_{2}$ emissions from exposed sediments in drawdown areas are about one order of magnitude higher than those from adjacent water surfaces. The current knowledge suggests that drawdown areas play a disproportionately important role in total $\mathrm{CO}_{2}$ emissions with respect to the area they cover. The fact that drawdown zones of reservoirs are $\mathrm{CO}_{2}$ emission hotspots has an important implication in light of a changing climate that may result in more frequent extended droughts throughout the world (Pachauri et al. 2014). Changing drawdown area extent may affect not only reservoir carbon emissions, but burial as well. Because submerged reservoir sediments typically act as carbon sinks and exposed sediments release a large fraction of organic carbon that would otherwise be buried for long timescales (Marcé et al. 2019), an increased drawdown area extent may reduce organic carbon burial efficiency on a reservoir scale. Finally, although we have not focused on methane emission, recent studies indicate that reservoir drawdown areas might be sites of intense methane release (Beaulieu et al. 2017;
Harrison et al. 2017; Yang et al. 2012), which is also temporally heterogeneous (Kosten et al. 2018). Carbon processing in drawdown areas deserves more attention to support better constrained upscaling of carbon emission from freshwaters.

Acknowledgements Open access funding provided by Uppsala University. We are grateful to Iollanda I. P. Josué for her assistance during field work. This work has been funded by the European Research Council under the European Union's Seventh Framework Programme (FP7/2007-2013)/ERC grant agreement $n^{\circ}$ 336642. S.S. received additional support by the program Pesquisador Visitante Especial, Ciência sem Fronteiras, $n^{\circ}$ 401384/2014-4, and J.R.P. received additional support by CAPES, scholarship $n^{\circ} 1703399$. N.B received additional support by Fundação de Amparo à Pesquisa do Estado de Minas Gerais/ FAPEMIG (CRA AP0 03045/16).

Open Access This article is distributed under the terms of the Creative Commons Attribution 4.0 International License (http://creativeco mmons.org/licenses/by/4.0/), which permits unrestricted use, distribution, and reproduction in any medium, provided you give appropriate credit to the original author(s) and the source, provide a link to the Creative Commons license, and indicate if changes were made.

\section{References}

Almeida RM, Pacheco FS, Barros N, Rosi E, Roland F (2017) Extreme floods increase $\mathrm{CO}_{2}$ outgassing from a large Amazonian river. Limnol Oceanogr 62:989-999. https://doi.org/10.1002/lno.10480

Beaulieu JJ et al (2017) Effects of an experimental water-level drawdown on methane emissions from a eutrophic reservoir. Ecosystems 21(4):657-674. https://doi.org/10.1007/s10021-017-0176-2

Bolpagni R, Folegot S, Laini A, Bartoli M (2017) Role of ephemeral vegetation of emerging river bottoms in modulating $\mathrm{CO}_{2}$ exchanges across a temperate large lowland river stretch. Aquat Sci 79:149-158. https://doi.org/10.1007/s00027-016-0486-z

Bond-Lamberty BP, Thomson AM (2012) A global database of soil respiration data, version 3.0. Oak Ridge, Tennessee. https://doi. org/10.3334/ORNLDAAC/1235

Catalán N, von Schiller D, Marcé R, Koschorreck M, Gómez-Gener L, Obrador B (2014) Carbon dioxide efflux during the flooding phase of temporary ponds. Limnetica 33:349-360

Cole JJ, Caraco NF (1998) Atmospheric exchange of carbon dioxide in a low-wind oligotrophic lake measured by the addition of SF6. Limnl Oceanogr 43:647-656

Deemer BR et al (2016) Greenhouse gas emissions from reservoir water surfaces: a new global synthesis. Bioscience 66:949-964. https://doi.org/10.1093/biosci/biw117

Descloux S, Chanudet V, Serça D, Guérin F (2017) Methane and nitrous oxide annual emissions from an old eutrophic temperate reservoir. Sci Total Environ 598:959-972. https://doi. org/10.1016/j.scitotenv.2017.04.066

Deshmukh C et al (2018) Carbon dioxide emissions from the flat bottom and shallow Nam Theun 2 Reservoir: drawdown area as a neglected pathway to the atmosphere. Biogeosciences 15:17751794. https://doi.org/10.5194/bg-15-1775-2018

Development Core Team R (2016) R: a language and environment for statistical computing, 3.3.2 edn. R Foundation for Statistical Computing, Vienna

Fenner N, Freeman C (2011) Drought-induced carbon loss in peatlands. Nat Geosci 4:895. https://doi.org/10.1038/ngeo1323 
Friedl G, Wüest A (2002) Disrupting biogeochemical cyclesconsequences of damming. Aquat Sci 64:55-65. https://doi. org/10.1007/s00027-002-8054-0

Furrer G, Wehrli B (1996) Microbial reactions, chemical speciation, and multicomponent diffusion in porewaters of a eutrophic lake. Geochim Cosmochim Acta 60:2333-2346. https://doi. org/10.1016/0016-7037(96)00086-5

Gallo EL, Lohse KA, Ferlin CM, Meixner T, Brooks PD (2014) Physical and biological controls on trace gas fluxes in semi-arid urban ephemeral waterways. Biogeochemistry 121:189-207. https://doi. org/10.1007/s10533-013-9927-0

Gilbert PJ, Cooke DA, Deary M, Taylor S, Jeffries MJ (2017) Quantifying rapid spatial and temporal variations of $\mathrm{CO} 2$ fluxes from small, lowland freshwater ponds. Hydrobiologia 793:83-93. https ://doi.org/10.1007/s10750-016-2855-y

Gómez-Gener L et al (2015) Hot spots for carbon emissions from Mediterranean fluvial networks during summer drought. Biogeochemistry 125:409-426. https://doi.org/10.1007/s10533-015-0139-7

Harrison JA, Deemer BR, Birchfield MK, O'Malley MT (2017) Reservoir water-level drawdowns accelerate and amplify methane emission. Environ Sci Technol 51:1267-1277. https://doi.org/10.1021/ acs.est.6b03185

Hyojin J, Tae Kyung Y, Seung-Hoon L, Hojeong K, Jungho I, Ji-Hyung P (2016) Enhanced greenhouse gas emission from exposed sediments along a hydroelectric reservoir during an extreme drought event. Environ Res Lett 11:124003

Kosten S et al (2018) Extreme drought boosts CO2 and CH4 emissions from reservoir drawdown areas. Inland Waters 8(3):329-340. https ://doi.org/10.1080/20442041.2018.1483126

Lesmeister L, Koschorreck M (2017) A closed-chamber method to measure greenhouse gas fluxes from dry aquatic sediments. Atmos Meas Tech 10:2377-2382. https://doi.org/10.5194/ amt-10-2377-2017

Li S, Zhang Q, Bush RT, Sullivan LA (2015) Methane and $\mathrm{CO}_{2}$ emissions from China's hydroelectric reservoirs: a new quantitative synthesis. Environ Sci Pollut Res 22:5325-5339. https://doi. org/10.1007/s11356-015-4083-9

Looman A, Maher DT, Pendall E, Bass A, Santos IR (2017) The carbon dioxide evasion cycle of an intermittent first-order stream: contrasting water-air and soil-air exchange. Biogeochemistry 132:87-102. https://doi.org/10.1007/s10533-016-0289-2

Machado PJO (2012) Diagnóstico ambiental e ordenamento territorial-instrumentos para a gestão da Bacia de Contribuição da Represa de Chapéu D’Uvas/MG. PhD thesis, Universidade Federal Fluminense, Brazil

Marcé R et al (2019) Emissions from dry inland waters are a blind spot in the global carbon cycle. Earth Sci Rev 188:240-248. https:// doi.org/10.1016/j.earscirev.2018.11.012

Nilsson C, Reidy CA, Dynesius M, Revenga C (2005) Fragmentation and flow regulation of the world's large river systems. Science 308:405-408. https://doi.org/10.1126/science.1107887

Obrador B, von Schiller D, Marcé R, Gómez-Gener L, Koschorreck M, Borrego C, Catalán N (2018) Dry habitats sustain high
$\mathrm{CO}_{2}$ emissions from temporary ponds across seasons. Scientific Reports 8:3015. https://doi.org/10.1038/s41598-018-20969-y

Pachauri RK et al (2014) Climate change 2014: synthesis report. Contribution of Working Groups I, II and III to the fifth assessment report of the intergovernmental panel on climate change, p. 151

Paranaíba JR et al (2018) Spatially resolved measurements of $\mathrm{CO}_{2}$ and $\mathrm{CH}_{4}$ concentration and gas-exchange velocity highly influence carbon-emission estimates of reservoirs. Environ Sci Technol 52:607-615. https://doi.org/10.1021/acs.est.7b05138

Pekel J-F, Cottam A, Gorelick N, Belward AS (2016) High-resolution mapping of global surface water and its long-term changes. Nature 540:418. https://doi.org/10.1038/nature20584

Reverey F, Grossart H-P, Premke K, Lischeid G (2016) Carbon and nutrient cycling in kettle hole sediments depending on hydrological dynamics: a review. Hydrobiologia 775:1-20. https://doi. org/10.1007/s10750-016-2715-9

Roland F et al (2010) Variability of carbon dioxide flux from tropical (Cerrado) hydroelectric reservoirs. Aquat Sci 72:283-293. https ://doi.org/10.1007/s00027-010-0140-0

Schiller DV, Marcé R, Obrador B, Gómez-Gener L, Casas-Ruiz JP, Acuña V, Koschorreck M (2014) Carbon dioxide emissions from dry watercourses. Inland Waters 4:377-382. https://doi. org/10.5268/IW-4.4.746

St. Louis VL, Kelly CA, Duchemin É, Rudd JWM, Rosenberg DM (2000) Reservoir surfaces as sources of greenhouse gases to the atmosphere: a global estimate. BioScience 50:766-775. https://doi.org/10.1641/0006-3568(2000)050\%5b0766:rsaso $\mathrm{g} \% 5 \mathrm{~d} 2.0 . \mathrm{co} ; 2$

Teodoru CR et al (2012) The net carbon footprint of a newly created boreal hydroelectric reservoir. Glob Biogeochem Cycles. https:// doi.org/10.1029/2011gb004187

Weise L et al (2016) Water level changes affect carbon turnover and microbial community composition in lake sediments. FEMS Microbiol Ecol 92:fiw035. https://doi.org/10.1093/femsec/fiw035

Yang L et al (2012) Surface methane emissions from different land use types during various water levels in three major drawdown areas of the Three Gorges Reservoir. J Geophys Res Atmos. https://doi. org/10.1029/2011jd017362

Yang L, Lu F, Wang X, Duan X, Tong L, Ouyang Z, Li H (2013) Spatial and seasonal variability of $\mathrm{CO}_{2}$ flux at the air-water interface of the Three Gorges Reservoir. J Environ Sci 25:2229-2238. https ://doi.org/10.1016/S1001-0742(12)60291-5

Zehnder AJB, Svensson BH (1986) Life without oxygen: what can and what cannot? Experientia 42:1197-1205. https://doi.org/10.1007/ BF01946391

Publisher's Note Springer Nature remains neutral with regard to jurisdictional claims in published maps and institutional affiliations. 